\title{
Painful ophthalmoplegia: a case report and literature review
}

\author{
Ağrılı oftalmopleji: Bir olgu sunumu ve literatür gözden geçirmesi
}

\author{
Ferda ILGEN USLU,' Mustafa ÖZKAN²
}

\begin{abstract}
Summary
Painful ophthalmoplegia consists of periorbital or hemicranial pain with ipsilateral ocular motor nerve palsies. There are many etiologies of painful ophthalmoplegia. Tolosa-Hunt syndrome (THS) is an uncommon disease caused by non-specific inflammation of the cavernous sinus, superior orbital fissure and the apex of the orbit. A 45-year-old female reported episodes of reversible left eye pain and diplopia. Examination showed periorbital oedema and left palpebral semiptosis, paresis of the partial left third nerve palsy with normal pupillary reactions, fourth and sixth left cranial nerves, and hypoesthesia over the first and second division of the left trigeminal nerve. Blood analysis, postcontrast cranial and orbital magnetic resonance (MR) imaging, cranial MR angiography and CSF analysis demonstrated no abnormalities. The clinical diagnosis satisfies the criteria for THS. After steroid therapy her symptoms and clinical signs dramatically reverses. Painful ophthalmoplegia with inflammatory conditions such as THS is highly responsive to corticosteroids but should be diagnoses of exclusion. The THS diagnosis should be used rarely and with great caution.
\end{abstract}

Keywords: Multiple cranial nerve palsy; painful ophthalmoplegia; Tolosa-Hunt syndrome.

\begin{abstract}
Özet
Ağrılı oftalmopleji periorbital veya hemikranyal başa ağrısı ile beraber ipsilateral okular motor sinir parezileri ile karakterizedir ve birçok değişik etiyoloji sonucu oluşabilir. Tolosa-Hunt Sendromu (THS) ağrılı oftalmopatiye neden olabilen, kavernöz sinus, superior orbital fissur ve orbat apeksinin nonspesifik inflamasyonu sonucu oluşan nadir bir hastalıktır. Burada sol göz ağrısı ve diplopi ile başvuran 45 yaşında kadın hasta sunuldu. Muayenesinde periorbital ödem ve sol palpebral semiptoz, sol parsiyel 3. kranyal sinir felci, 4., 6. felci ve 5. sinir oftalmik ve maksiller divizyon alanında hiposetezi saptandı. Kan analizi, postkontrast kraniyal ve orbital magnetik resonans görüntülemesi ve BOS incelemesinde patoloji saptanmadı. Klinik tanısı THS kriterlerini dolduruyordu. Steroid tedavisi sonrası semptom ve bulguları tamamen düzeldi. Ağrılı oftalmopleji THS gibi enflamatuvar durumlar ile birlikte olabilir ve bu durumda steroid tedavisine tam aynıtlıdır, fakat mutlaka iyi bir ayırıcı tanı yapılmalıdır. THS tanısı nadiren kullanılması gereken bir tanıdır.
\end{abstract}

Anahtar sözcükler: Multipl kraniyal sinir felci; ağrılı oftalmopleji; Tolosa-Hunt sendromu.

\section{Introduction}

The painful ophthalmoplegia syndrome is a condition which involves periorbital or hemicranial pain combined with ipsilateral paralysis of the common oculomotor nerve and loss of sensitivity in the distribution of the ophthalmic branch and/or maxillary of the trigeminal nerve. ${ }^{[1]}$ Painful ophthalmoplegia can result from neoplasic, vascular, inflammatory or infectious disease. ${ }^{[2]}$ Tolosa-Hunt syndrome (THS) is one of the uncommon reason of painful opthalmoplejia.
According to the International Headache Society Classification of 2004, THS is an entity that occurs rarely, its etiopathogenesis is unknown, it is manifested clinically by unilateral orbital pain associated with simple or multiple oculomotor paralyses, which resolves spontaneously but may recur. MRI orbital phlebography and biopsy are the recommended methods for making diagniosis..$^{[3]}$ The clinical presentation of THS has a wide differential diagnosis, can

'Department of Neurology, Antalya Ataturk State Hospital, Antalya, Turkey

${ }^{2}$ Antalya Yasam Hospital, Antalya, Turkey

Submitted: 13.04.2014 Accepted after revision: 10.06.2014

Correspondence: Dr. Ferda Illgen Uslu. Antalya Ataturk State Hospital, Antalya, Turkey.

Tel: +90 - 242 - 3454550 e-mail: ferdailgen@yahoo.com

(c) 2015 Turkish Society of Algology 

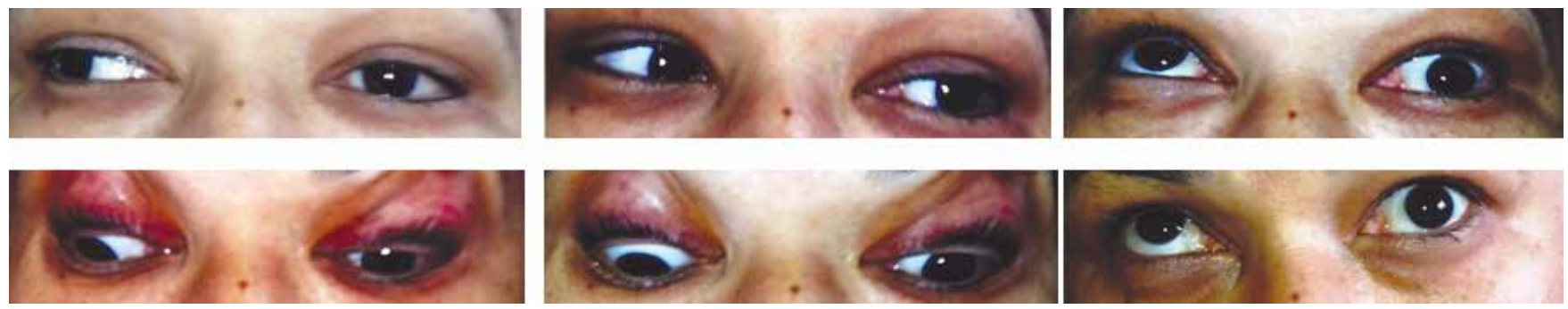

Figure 1. Neuro-ophthalmologic examination prior treatment shows left palpebral ptosis, exotropia of the primary look of the left eye, paresis of the third, fourth and sixth left cranial nerves.

greatly assist clinicians with early accurate diagnosis and management. ${ }^{[4]}$

Herein we report a 45-year-old women with painful ophthalmoplegia of the left eye secondary to the THS, it's diagnostic procedures and treatment.

\section{Case Report}

A 45-year-old women was first seen in emergengcy department with severe pain behind the left eye, numbness of the left side of the face, and diplopia.. The pain was over the left eyebrow, nose and nose wing root and started 4 mounths ago. Her attacks was abrupt, brief, lasting only seconds but becoming more frequent over time. She described as heavy, stabbing and burning. Symptoms were poorly controlled with antibiotics and nonsteroidal anti-inflammatory drugs. Cranial MRI and intra-extracarnial MR Anjiography was normal in the first month. Gabapentin $600 \mathrm{mg} /$ day was started but all this treat- ments have failed. Whereupon carbamazapine 400 $\mathrm{mg} /$ day was started, 3 day later increased to $800 \mathrm{mg} /$ day. The patient's pain improved with this treatment. But during the first week of drug continuous throbbing pain behind his left eye started when she wake up in the morning. After 3 days later the patient was admitted to the hospital. In emergency room her vitals were normal. Examination showed periorbital oedema and left palpebral semiptosis, paresis of the partial left third nerve palsy with normal pupillary reactions, fourth and sixth left cranial nerves, and hypoesthesia over the first and second division of the left trigeminal nevre (Figure 1).

Visual acuity and the fundus was normal. There was no proptosis, and the rest of the neurological and systemic examination was normal. Her relevant medical history only included smoking 20 packs/ years. She had not history of headaches, diabetes mellitus, hipertansiyon or any anohter illness.
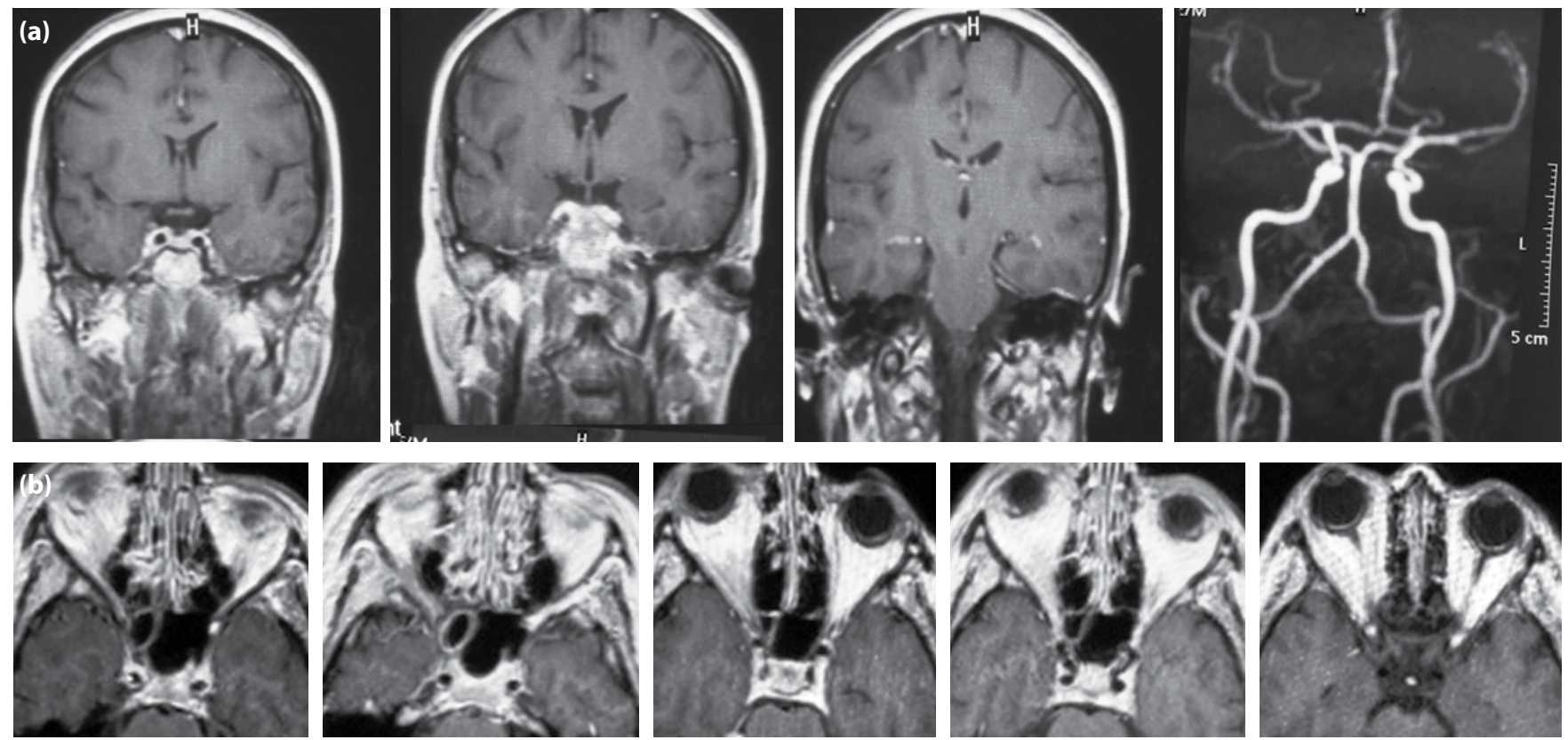

Figure 2. Coronal 11 scan of brain MRI with contrast, MR-Anjiography (a) and axial T1 scan of orbital MRI (b) with contrast. There was no evidence to explain the symptoms. 

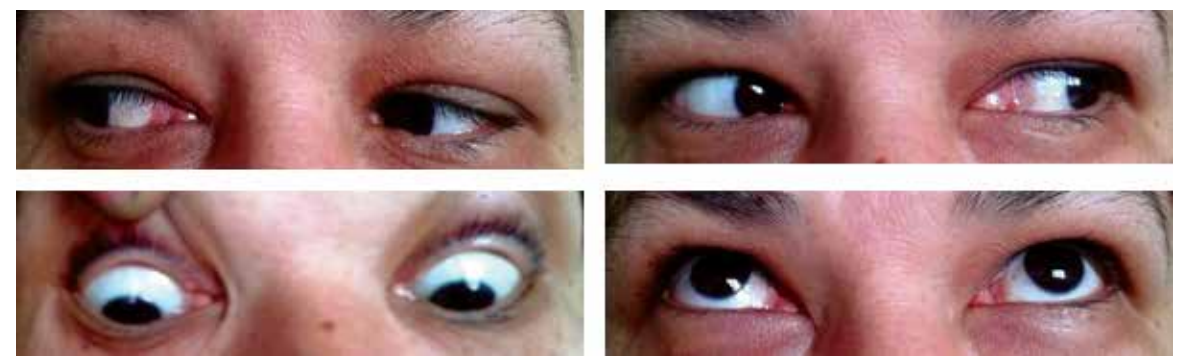

Figure 3. After treatment neuro-ophthalmologic examination was completely normal.

We performed the following complementary studies: normal hemogram and biochemistry including glucose level, normal basic coagulation, ESR, lues serology and vasculitis markers. Thyroid function tests showed TSH: $9.6 \mu \mathrm{Ul} / \mathrm{ml}(0.34-5.60)$, free T4: $0.40 \mathrm{ng} /$ dl [0.54-1.64]. Anti-thyroglobulin, anti-microsomal and anti-thyrotropin receptor were normal. An urgent cranial computed tomography (CT) scan of brain and paranasal sinus, were normal. The cranial MRI with a study in T1-T2 weighted sequences, with gadolinium in both orbits, and MR-Anjiography of the brain were normal, no evidence of alterations in the cavernous sinus (Figures 2a, b). A spinal tap was performed. CSF yielded normal opening pressure, cellularity, glucose, proteins and red blood cells. Normal supraaortic trunks duplex. She had newly diagnosed, untreated hypothyroidism but thyroidassociated orbitopathy were excluded. Because her pain's character was neuropathic, hypothyroidism was not autoimmune and ocular manifestations and orbital imaging were not typical for Graves' ophthalmopathy. Since the studies showed no abnormalities and we excluded neoplasic, infectious, vascular and metabolic causes of her painful ophthalmoplegia caused by the THS. Our patient with idiopathic painful ophthalmoplegia fulfilled THS criteria (A, B, C, $D$ and E) (Table 1). Her treatment for THS was started with methylprednisolone $1 \mathrm{gr}$ intravenous/day for 5 days, and noticed significant improvement in terms of the left periorbital pain and the ipsilateral ocular motor nerve palsies in the next 48 hours. Then at day 6 , she received $60 \mathrm{mg}$ of methylprednisolone per os ( $1 \mathrm{mg} / \mathrm{kg} / \mathrm{day})$. One week later, she initiated steroid tapering every week and the dose was gradually decreased for 2 months. The newly diagnosed hypothyroidism was treated by Eutrox $50 \mathrm{mg} /$ day. Upon completion of treatment, full remission of the condition was attained, the patient was asymptomatic and her neuro-ophthalmologic examination was completely normal (Figure 3).
Table 1. ICHD-II classification part three. Cranial neuralgias, central and primary facial pain and other headaches 13.16 Tolosa-Hunt syndrome

Description

Episodic orbital pain associated with paralysis of one or more of the third fourth and/or sixth cranial nerves which usually resolves spontaneously but tends to replase and remit.

Diagnostic criteria

A. One or more episodes of unilateral orbital pain persisting for weeks if untreated.

B. Paresis of one or more of the third, fourth and/or sixth cranial nerves and/or demonstration of granulomas by MRI or biopsy.

C. Paresis coincides with the onset of pain or follows it within 2 weeks.

D. Pain and paresis resolve within $72 \mathrm{~h}$ when treated adequately with corticosteroids.

E. Other causes have been excluded by appropriate investigations 1

Note

1. Other causes of painful ophthalmoplegia include tumours, vasculitis, basal meningitis, sarcoid, diabetes mellitus a ophthalmoplegic 'migraine'.

Comments

Some reported cases of Tolosa-Hunt syndrome had additional involvement of the trigeminal nerve [commonly the first; division] or optic, facial or acoustic nerves.

Sympathetic innervation of the pupil is occasionally affected.

The syndrome has been caused by granulomatous material in the cavernous sinus, superior orbital fissure or orbit in some biopsied cases.

Careful follow-up is required to exclude other possible causes of painful ophthalmoplegia.

\section{Discussion}

In our patient her full blood count, biochemistry, brain and sinus CT, brain and orbital MRI with gadolinium, MR-anjiography and CSF were normal. She had newly diagnosed, untreated hypothyroidism 
but thyroid-associated orbitopathy were excluded. Because her pain's character was neuropathic, her hypothyroidism was not autoimmune and ocular manifestations and orbital imaging were not typical for Graves' ophthalmopathy. So the case described herein corresponds to an orbital involvement which suggested involvement of the cavernous sinus due to an associated inflammatory disease. We thought that the patient had THS because she completely fulfilled HIS 2004 diagnostic criteria, and since without significant findings in the in her neuroimaging and CSF, she had a benign variety of THS.

Painful ophthalmoplegia often refers to a multiple cranial nerve syndrome involving the oculomotor, trochlear, and abducens nerves and the ophthamic division of the trigeminal nerve. Various etiologies have been reported; these include infections, inflammations, granulomatous process, sphenoid sinus mucocele, local tumors, dural arteriovenous malformation, trauma, and diabetes mellitus. ${ }^{[5]}$

Unilateral painful ophthalmoplegia can be acute, chronic, relapsing, and remitting [spontaneusly or in association with steroid withdrawal and treatment] or progressive. ${ }^{[6]}$

Tolosa-Hunt syndrome is a rare disorder indicated by recurrent painful ophthalmoplegia caused by nonspecific inflammation of the cavernous sinus or superior orbital fissure. Tolosa first described the condition in 1954, in a patient with unilateral recurrent painful ophthalmoplegia involving cranial nerves III, $\mathrm{IV}, \mathrm{VI}$ and $\mathrm{V} 1$. The patient was imaged using carotid angiography, and segmental narrowing of the carotid siphon was seen $\cdot{ }^{[7]}$ Hunt et al. described 6 patients with similar clinical findings in 1961, and proposed a low-grade non-specific inflammation of the cavernous sinus and its walls as the cause of the syndrome. ${ }^{[8]}$ Painful ophthalmoplegia secondary to idiopathic granulomatous inflamation of the cavernous sinus or the superior orbital fissure that is steroid responsive was given the eponym THS by Smith and Taxdal in $1966 .{ }^{[5]}$ Pathologically, infiltration of lymphocytes and plasma cells as well as thickening of the dura mater was seen. ${ }^{[4,7,8,9]}$

Clinically, the hallmark of this disorder is pain, which can be severe or a deep ache associated varying degrees of ophthalmoplegia, ptosis and diplopia. The symptoms and signs depend on the location of inflammation. If the orbit is involved, conjunctival injection avd chemosis, orbital conjection and proptosis, lacrimal gland injection and swelling can be observed. Immediate response to steroid therapy is a hallmark of the condition. THS criteria was first provided by the International Headache Society [IHS] in 1988, ${ }^{[10]}$ and modified (Table 1) in the revised IHS headache classification of 2004. ${ }^{[6]}$ THS can be classified, according to neuroimaging in benign [when no abnormal neuroimaging can be found], inflammatory [when inflammatory findings are shown on MRI or biopsy] and symptomatic [when neuroimaging reveals specific lesion]. ${ }^{[11]}$

THS essentially remains a diagnosis of exclusion, differential diagnosis is very important. The differential diagnosis of painful ophthalmoplegia is extensive and consists of numerous sinister etiologies, including vascular [eg, carotid cavernous fistula, parasellar region carotid cavernous aneurysm, cavernous sinus thrombosis, carotid dissection], neoplasms [ie, pituitary adenoma, sarcoma, neurofibroma, epidermoid, craniopharyngioma, meningioma, chordoma, chondroma, giant cell tumor, metastases, lymphoma, carcinomatous meningitis local or distant metastases], inflammatory [ie, sarcoidosis, Wegener's granulomatosis, THS orbital pseudotumor, giant cell arteritis], and infectious etiologies [ie, bacterial sinusitis, periostitis, mucormycosis, syphilis, fungal and mycobacterial], as well as other miscellaneous conditions [ie, ophthalmoplegic migraine, trauma and microvascular infarcts secondary to diabetes]. ${ }^{[6]}$

Neuroimaging and CSF are important in differantial diagnosis. Also full blood count, ESR, $\mathrm{C}$ reactive protein, full biochemistry tests including thyroid and liver functional tests, Chest $X$ ray and Sinus CT may also be indicated. Barin and orbital imaging includes MRI and CT scan. MRI (T2-weighted including fat suppression STIR Sequence) helps to identify high signals in an active extra-ocular muscle. Inflammatory causes of painful ophthalmoplegia include those due to a specific infectious agent. It is essential that careful CSF examination be done and that cultures (bacterial, fungal, mycobacterial) be obtained.

The management of patients with painful ophthal- 
mopathy is complex and challenging. Neurologists, ophthalmologists, pathologists and neuroradiologists all play important roles in establishing the correct diagnosis. The THS diagnosis should be used rarely and with great caution, as most cases are ultimately attributable to defined disease processes such as infection, granulomatous inflammation or neoplasm. That patients suspected of having the syndrome require careful evaluation, appropriate treatment, and scrupulous follow up observation. ${ }^{[12]}$

\section{Conflict-of-interest issues regarding the authorship or article: None declared.}

\section{Peer-rewiew: Externally peer-reviewed.}

\section{References}

1. Mora-de-Oñate J, Pascual-Pérez-Alfaro $R$, IzquierdoVázquez C, González-Ruiz M, Aguirrebeña-Olmos A, DíezVillalba R. Painful ophthalmoplegia (pseudotumor of the orbit and Tolosa-Hunt syndrome). [Article in Spanish] Arch Soc Esp Oftalmol 2007;82(8):509-12. [Abstract]

2. Gladstone JP. An approach to the patient with painful ophthalmoplegia, with a focus on Tolosa-Hunt syndrome. Curr
Pain Headache Rep 2007;11(4):317-25.

3. Paović J, Paović P, Bojković I, Nagulić M, Sredović V. TolosaHunt syndrome-diagnostic problem of painful ophthalmoplegia. Vojnosanit Pregl 2012;69(7):627-30.

4. Barnard B, Hurter D, Roux F, Aboobaker S. Tolosa-Hunt syndrome. SA Journal of Radiology 2012;16(1):14-5.

5. Kwan ES, Wolpert SM, Hedges TR 3rd, Laucella M. TolosaHunt syndrome revisited: not necessarily a diagnosis of exclusion. AJR Am J Roentgenol 1988;150(2):413-8.

6. Lance JW, Olesen J. The International Classification of Headache Disorders ICHD-II. Cephalalgia 2004;24:131.

7. Tolosa E. Periarteritic lesions of the carotid siphon with the clinical features of a carotid infraclinoidal aneurysm. J Neurol Neurosurg Psychiatry 1954;17(4):300-2.

8. Hunt WE, Meagher JN, LeFever HE, Zeman W. Painful opthalmoplegia. Its relation to indolent inflammation of the carvernous sinus. Neurology 1961;11:56-62.

9. Som PD, Curtin HD. Head and neck imaging. $4^{\text {th }}$ ed. St Louis: Mosby; 2003.

10. Headache Classification Committe of the International Headache Society. Classification and diagnostic criteria for headache disorders, cranial neuralgias and facial pain. Cephalalgia 1988;8(Suppl):1-96.

11. Brazis PW. Localization in clinical neurology. 4th ed. Philadelphia: Williams \& Wilkins; 2001.

12. Kline LB, Hoyt WF. The Tolosa-Hunt syndrome. J Neurol Neurosurg Psychiatry 2001;71(5):577-82. 